\title{
Brand Loyalty in Hospitality Sector in India: A Case study of Indian Hotels in Goa-Kerala.
}

\author{
Dr. Jaskaran Singh Dhillon, Director Principal \\ Swift Institute of Management and Computer Science Swift Technical Campus, Rajpura- Punjab, India
}

\begin{abstract}
In general, perceived service quality seems to be positively related to customers' likelihood of remaining a loyal customer and their attitudes toward the service provider (Anton, Camarero, \& Carrero, 2007; Bell, Auh \& Smalley, 2005; Aydin \& Ozer, 2005). Suhartanto (2011) reported that there are numerous studies, mostly conducted in developed countries, which examined service quality as the determinant of customers' brand loyalty in the hotel industry. This prompted the researchers to investigate empirically how and to what degree customers' perceptions on service quality dimensions impact their hotel brand loyalty in developing country - India. Multiple regression analysis, on survey responses of the customers of 8 different four and five star hotels, reflected that customers' perceptions on tangibles, empathy and reliability contributed to fostering their loyalty with hotel brands. Implications for practitioners and future researchers were discussed, too.

Keywords: Hospitality Sector, Service Quality, Brand Loyalty, Hotel Industry.
\end{abstract}

\section{Introduction}

Berry (2000) claimed that branding is regarded as the cornerstone in $21^{\text {st }}$ century while taking service marketing domain in to consideration. Today's researchers declared the brand as the most influential character in services because of its innate distinctiveness like perish ability, inseparability, tangibility and heterogeneity (Kapferer, 2004). The emergence of brand equity raised its importance in researchers and brand manager equally (Keller, 2003) but it also had significant differences in the defining and measuring brand equity (Bailey and Ball, 2006; Keller and Lehmann, 2006).

The hotel industry, in particular, and all businesses whose service depend on building long term relationship need to concentrate on maintaining customer's loyalty. To achieve a sustainable competitive advantage in the marketplace, one has to value the importance of building, using and maintaining brands. For this reason, academics and practitioners have studied the concept and measurement of brand equity for more than a decade (Kim, Kim \& An, 2003). Prasad and Dev (2000) are of the opinion that branding is an effective method for hotels and hotel chains to identify and distinguish themselves from competitors in the mind of the customer. The hotel industry isn't a new vertical for India by any measure. The 2011 World Economic forum's Travel and Tourism Competitiveness Report (TTCR) ranked India 68 out of 124 countries to visit; which predicted a gloomy picture for hotels as well; which mainly depends on tourism in India. India has slipped 6 positions from position no. 62 in 2009.

Bailey and Ball (2006) defined hotel based brand equity as "the value that consumers and hotel property owners associate with a hotel brand and the impacts of these associations on their behavior". Prasad and Dev (2000) and later on, Forgacs (2003) found that extensive strategies have been applied for the development and prolific growth of new branded hotels over the last five years, worldwide. This overabundance of hotel brands has given rise to severe confusion among customers according to the arguments of Gibson (2003), Olsen et al. (1998) and Kim et al. (2008). Now it clearly demanded efforts to enhance and enrich the specific knowledge related to hotel brand management, so that improved and better decision making related to marketing activities could be recognized and practiced to stand high in the crowd.

As suggested Al-Rousan, Ramzi \& Mohamed (2010), the relationship at the level of dimensions has remained virtually unexplored. To add to the limited literature on hotel service industry, the present study intended to contribute to the literature of hotel brand equity, specifically, and service brand equity, generally. It also promises significant 'go ahead' for researchers to explore the effect of perceived service quality on brand loyalty. And due to the lack of empirical research in this particular domain (Cobb-Walgren et al., 1995; Prasad and Dev, 2000; Kim and Kim, 2005; Kayaman \& Arasli, 2007), this study gains more importance. Besides, findings of the research would result in deeper and better understandings of the concept of hotels' service quality and its subsequent effects on brand loyalty in theory especially in India. 


\section{Literature Review}

Service quality was defined by Zeithaml (1988) as "the judgment of customers about the overall superiority of a product or service." Gronroos (1988) posited that perceived quality is considered good when the experienced quality of customers meets the expected quality from the brand. The literature considers perceived service quality as a "core/primary" aspect across customer-based brand equity landmark frameworks (Farquhar, 1989; Keller, 1993; Aaker, 1996; Dyson et al., 1996). It provides customers with a reason to purchase and enhances customer value by equipping the brand with differentiation and prominent positioning among competitor's brands.

In customer based brand equity (CBBE) model, perceived quality is considered as the primary facet (Dyson et al., 1996).

\section{Core /Primary CBBS Facets}

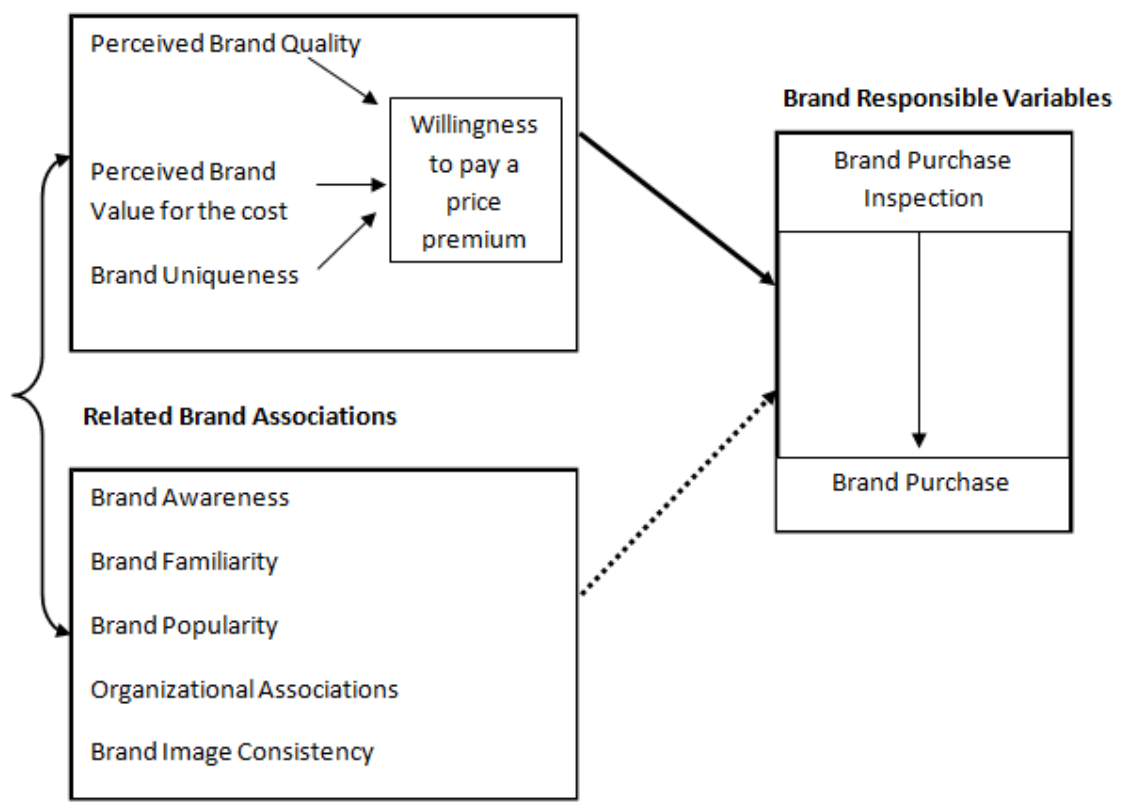

Many researchers conceptualized various dimension of perceived service quality like, landmark study of Knutson et al. (1990), Oberoi and Hales (1990) work in UK based hotel settings, Getty and Thompson (1994) study on Spanish hotel industry, SERVPERF model developed by Cronin and Taylor (1992), Ekinci (1998) work in hotel industry of Turkey, Wilkins et al. (2007) work on hotel service industry, "HOLSERV" scale of Mei et al. (1999) in the hotel industry of Australia, studies ranging from supermarkets to travel agencies and from information services to hotel industries (Bigne' et al., 2003; Akbaba, 2006; Landrum et al., 2007; Roses et al., 2009), five service quality dimensions in the hospitality industry by Saleh and Ryan (1991), six dimensions developed by Khan (2003) in ecotourism industry, "lodging quality index" by Getty and Getty (2003) in USA hospitality market, nine dimensional scale by Juwaheer (2004) developed in the Mauritian hotel industry and then a five-dimensional scale by Albacete-Saes et al. (2007) in rural accommodation industry. The most famous model of service quality was proposed by Parasuraman et al. $(1985,1988)$. It had five dimensions and can be explained as:

1st- Reliability: "the degree to which a promised service is performed dependably and accurately".

2nd -Responsiveness: "the degree to which service providers are willing to help customers and provide prompt service".

3rd - Assurance: "the extent to which service providers are knowledgeable, courteous, and able to inspire trust and confidence".

4th - Empathy: "the degree to which the customers are offered caring and individualized attention".

5th- Tangibles: "the degree to which physical facilities, equipment, and appearance of personnel are adequate".

The perception of customers about quality was predicted to be linked with their loyalty with brand because favorable perception about the brand quality leads to more and more brand loyal customers. That's why Bolton and Drew (1991) suggested "service quality has significant effects on 
customer loyalty". In general, perceived service quality seems to be positively related to customers' likelihood of remaining a loyal customer and their attitudes toward the service provider i.e. brand loyalty (Anton, Camarero, \& Carrero, 2007; Bell, Auh \& Smalley, 2005; Aydin \& Ozer, 2005). Among others, Jones et al. (2002) found a significant relationship between perceived quality and customer loyalty. To report the direct relation between perceived service quality and brand loyalty, existence of a significant and positive relationship between the perceptions of customers related to service quality and their intentions to buy and, subsequently, willingness to recommend the company (positive word of mouth) is very much evident in various studies (Parasuraman et al., 1988; 1991).

Conflicting findings regarding the relationships between service quality and brand loyalty are also found in empirical studies in the hotel context. Kandampully and $\mathrm{Hu}$ (2007) and Kim et al. (2008) did not find a significant relationship between service quality and brand loyalty. Lai et al. (2009) found indirect relationships between service quality and brand loyalty through perceived value. Kayaman and Arasli (2007) reported that only tangible and responsiveness dimension has significant effect on brand loyalty. Others report indirect relationship between service quality and brand loyalty through perceived value and customer satisfaction (Chitty et al., 2007). Suhartanto (2011) reported that there are a number of studies examining service quality as the determinant of brand loyalty in the hotel industry, mostly conducted in developed countries. Some of these studies are bivariate studies in that they examine brand loyalty with service quality (Alexandris et al., 2002; Juwaheer, 2004). Cretu and Brodie (2007), Michell et al., (2001) and Jones et al., (2002) also found significant and positive association among perceived service quality with brand loyalty. So,

Study Hypothesis: Hotel customers' perceptions regarding SERVQUAL dimensions (assurance, tangibles, reliability, responsiveness and empathy) will have differential positive impact on their brand loyalty

\section{Research Methods}

Data was collected from multiple cities of Goa and Kerala who used services of eight renowned four and five stars hotel operating in India. Survey questionnaires were personally administered during Nov-December, 2011 - the peak season in the area.. After multiple follow-ups, 190 questionnaires were successfully retrieved. The SERVQUAL items in the questionnaire were adapted from the pioneering study conducted by Parasuraman et al's (1988) having five dimensions namely, tangibles, reliability, responsiveness, assurance and empathy. Kim and Kim (2005) scales were used for measuring brand loyalty (6items). The 5-point Likert scale was used to measure five dimensions of service quality and customer loyalty where " 1 = strongly disagree" and " $5=$ strongly agree". Stepwise regression analysis was employed to test the research hypothesis.

\section{Results and Discussion}

The demographic statistics of four and five star hotel customers indicated that $149(78 \%)$ male customers participated in this study besides 41 (22\%) females. Sixty four percent respondents earned Master degrees whereas only $36 \%$ were undergraduates. Thirty percent were employed by private organizations, 15 percent were businessmen and only 6 percent were from government sectors.

The descriptive statistics such as mean, standard deviation and inter correlations of all study variables are presented in Table 1.

\begin{tabular}{|c|c|c|c|c|c|c|c|c|}
\hline & Mean & Std. Deviation & $\mathrm{X} 1$ & $\mathrm{X} 2$ & $\mathrm{X3}$ & $\mathrm{X} 4$ & $\mathrm{X5}$ & X6 \\
\hline $\mathrm{X1}$ & 3.9 & 0.37 & 1.00 & & & & & \\
\hline $\mathrm{X} 2$ & 4.03 & 0.44 & $0.51 *$ & 1.00 & & & & \\
\hline X3 & 3.83 & 0.48 & $0.52 *$ & $0.38^{*}$ & 1.00 & & & \\
\hline $\mathrm{X4}$ & 3.91 & 0.52 & $0.48^{*}$ & $0.34 *$ & $0.60 *$ & 1.00 & & \\
\hline $\mathrm{X5}$ & 3.97 & 0.48 & $0.39 *$ & $0.45^{*}$ & $0.51^{*}$ & $0.46^{*}$ & 1.00 & \\
\hline X6 & 3.82 & 0.55 & $0.52 *$ & $0.43^{*}$ & $0.60^{*}$ & $0.64 *$ & $0.54 *$ & 1.00 \\
\hline
\end{tabular}


Table \# 2 displays the results of stepwise regression analysis in which customers perceptions on dimensions of service quality such as tangibles, empathy, reliability, assurance and responsiveness were regressed on brand loyalty. The results indicated that overall about $40 \%$ variance (adjusted $\mathrm{R}^{2}=0.40$ ) was explained by the perceptions regarding SERVQUAL dimensions like "reliability", "tangibles" and "empathy". Brand reliability perceptions alone Explained 27\% variability $\left(\mathrm{R}^{2}\right.$ change $\left.=.27\right)$ whereas tangibles and empathy perceptions accounted for only $11 \%\left(\mathrm{R}^{2}\right.$ change=.11) and about 3\% ( $\mathrm{R}^{2}$ change=.03) variance in brand loyalty respectively. However customers' perceptions on "responsiveness" and "empathy" did not influence their loyalty with hotel brand.

\begin{tabular}{|c|c|c|c|c|c|c|c|c|c|c|}
\hline \multirow[b]{2}{*}{ Model } & \multirow[b]{2}{*}{$\mathbf{R}$} & \multirow[b]{2}{*}{$\begin{array}{c}\mathrm{R} \\
\text { Square }\end{array}$} & \multirow[b]{2}{*}{$\begin{array}{l}\text { Adjusted } \\
\text { R Square }\end{array}$} & \multirow{2}{*}{$\begin{array}{l}\text { Std. Error } \\
\text { of the } \\
\text { Estimate }\end{array}$} & \multicolumn{5}{|c|}{ Change Statistics } & \multirow[b]{2}{*}{$\begin{array}{l}\text { Durbin- } \\
\text { Watson }\end{array}$} \\
\hline & & & & & $\begin{array}{c}\mathrm{R}^{2} \\
\text { Change }\end{array}$ & $\begin{array}{c}\mathrm{F} \\
\text { Change }\end{array}$ & dfl & df2 & $\begin{array}{c}\text { Sig. F } \\
\text { Change }\end{array}$ & \\
\hline 1 & $.52^{\mathrm{a}}$ & .27 & .27 & 0.32 & 0.27 & 62.32 & 1 & 165 & .000 & \\
\hline 2 & $.62^{b}$ & .39 & .38 & 0.29 & 0.11 & 29.51 & 1 & 164 & .000 & \\
\hline 3 & $.64^{c}$ & .42 & .40 & 0.29 & 0.03 & 08.46 & 1 & 163 & .004 & 2.10 \\
\hline
\end{tabular}

\section{Table 3: ANOVA (Dependent Variable: Brand Loyalty)}

\begin{tabular}{|l|l|c|c|c|c|c|}
\hline \multicolumn{2}{|c|}{ Model } & Sum of Squares & df & Mean Square & F & Sig. \\
\hline \multirow{3}{*}{3} & Regression & 9.410 & 3 & 3.137 & 38.578 & .000 \\
\cline { 2 - 7 } & Residual & 13.254 & 163 & .081 & & \\
\cline { 2 - 7 } & Total & 22.664 & 166 & & & \\
\hline \multicolumn{2}{|l|}{ a. Predictors: (Constant), Reliability, b. Predictors: (Constant), Reliability; Tangibles, c. Predictors: (Constant), Reliability, Taugibles, Empathy } \\
\hline
\end{tabular}

ANOVA results (Table 3) are indicative of predictive strength $\left(\mathrm{F}_{3,163}=38.578, \mathrm{p}<.001\right)$ of the empirical model suggesting its appropriateness for explaining variance in brand loyalty.

\begin{tabular}{|c|c|c|c|c|c|c|c|c|c|c|}
\hline \multirow{2}{*}{ Model } & \multicolumn{2}{|c|}{$\begin{array}{l}\text { Unstandardized } \\
\text { Coefficients }\end{array}$} & \multirow{2}{*}{$\begin{array}{c}\begin{array}{c}\text { Standardized } \\
\text { Coefficients }\end{array} \\
\text { Beta }\end{array}$} & \multirow{2}{*}{$t$} & \multirow{2}{*}{ Sig. } & \multicolumn{3}{|c|}{ Correlations } & \multicolumn{2}{|c|}{$\begin{array}{l}\text { Collinearity } \\
\text { Statistics }\end{array}$} \\
\hline & B & $\begin{array}{c}\text { Std. } \\
\text { Error }\end{array}$ & & & & $\begin{array}{l}\text { Zero- } \\
\text { order }\end{array}$ & Partial & Part & Tolerance & VIF \\
\hline (Constant) & 1.46 & 0.23 & & 6.38 & .000 & & & & & \\
\hline Reliability & 0.21 & 0.06 & 0.27 & 3.62 & .000 & 0.52 & 0.27 & 0.22 & 0.63 & 1.60 \\
\hline Tangibles & 0.25 & 0.06 & 0.31 & 4.53 & .000 & 0.51 & 0.33 & 0.27 & 0.79 & 1.26 \\
\hline Empathy & 0.16 & 0.05 & 0.23 & 2.91 & .004 & 0.52 & 0.22 & 0.17 & 0.59 & 1.68 \\
\hline
\end{tabular}

Beta coefficients (table \# 4) reflect how and to what extent customers' perceptions on perceived service quality dimensions had an impact on their brand loyalty. As shown, favorable perceptions regarding hotel tangibles (beta $=.31, \mathrm{t}=4.53, \mathrm{p}<0.001$ ) posted higher positive impact on brand loyalty than did reliability (beta=.27, $\mathrm{t}=3.62, \mathrm{p}<0.001$ ) and empathy (beta=.23, $\mathrm{t}=2.91, \mathrm{p}<$ 0.01). However, responsiveness and assurance did not play any role in making customers' loyal to their hotels. So, research hypothesis was partially supported by empirical evidence. The study observations are consistent with what was revealed in Al-Rousan et al. (2010) study that tangibles, reliability and empathy positively contributed to brand loyalty whereas assurance didn't play any role in building making customers loyal to their hotels.

\section{Conclusion and Recommendations}

The main aim of this research was to determine differential impact of customers' perceptions regarding SERVQUAL dimensions on their hotel brand loyalty. Based on study findings, it can be concluded that customers' perceptions regarding hotel brand quality dimensions such as "tangibles", "reliability" and "empathy" contributed to build their brand loyalty. Interestingly, favorable perceptions on hotel tangibles predicted relatively stronger brand loyalty than did reliability and empathy 
perceptions.

Today, competition is a primary challenge in the hospitality industry and the solution lies not only in increasing market share, and then preserving it accordingly, but also keeping them intact with the brand. As discussed earlier, in highly competitive war-field, a brand loyal customer profile is critical for a hotel brand. Our study recommends a stronger role of service quality and one of the strategies to create such a loyal customer profile is to develop a unique ambiance, an exclusive tangibilized atmosphere and a service delivery ensuring empathy and reliability. The staff's politeness, responsiveness, timely service and empathy plays a strong positive role in instigating a sense of belongingness in the customers; which means a strong brand loyalty because employee's behavior and attitude shape customers' overall perceptions about the brand.

This study also has several limitations. Firstly, this study targeted only four/five-star hotels. So the results cannot be generalized on the entire hotel industry. Secondly, conducting this research by using probability sampling method will compensate the limitation of non probability sampling method used in this study. In spite of a lot of literature on brand equity, it has been difficult to offer a full description of the nature of the hotel brand equity construct. To the best knowledge of the researchers, this research examined the impact of only two dimensions of brand equity for hotels. Still, there may be some other dimensions that have not been identified in the conceptual framework of this study. There is a dire need to extend this study to the categories in chain restaurant, cafe and motel settings.

\section{References}

[1]. Aaker, D.A. (1996). Building Strong Brands, the Free Press, New York, NY. ASHE Higher Education Report, $2005,31(2), 27-37$.

[2]. Akbaba, A. (2006). Measuring service quality in the hotel industry: A study in a business hotel in Turkey. International Journal of Hospitality Management, 25(2), 170-192.

[3]. Albacete-Saes, C.A., Fuentes-Fuentes, M.M., Lloréns-Montes, F.J. (2007), "Service quality measurement in rural accommodation", Annual of Tourism Research, Vol. 34 No.1, pp.45-65.

[4]. Alexandris, K., Dimitriadis, N., \& Markata, D. (2002). Can perceptions of service quality predict behavioural intentions? An exploratory study in the hotel section in Greece. Managing Service Quality, 12(4), 224-232.

[5]. Al-Rousan, M. Ramzi, Badaruddin Mohamed (2010), "Customer Loyalty and the Impacts of Service Quality: The Case of Five Star Hotels in Jordan", International Journal of Human and Social Sciences 5:13 2010

[6]. Anton , C. , Camarero , C. , \& Carrero , M. ( 2007 ). Analysing firms' failures as determinants of consumer switching intentions: The effect of moderating factors, European Journal of Marketing, 41 ( 1/2 ), 135 -158

[7]. Aydin, S., \& Ozer, G. (2005). The analysis of antecedents of customer loyalty in the Turkish mobile telecommunication market. European Journal of Marketing, 39(7/8), 910-925.

[8]. Bailey, R. and Ball, S. (2006), “An exploration of the meanings of hotel brand equity”, The Service Industries Journal, Vol. 26 No. 1, pp. 1538.

[9]. Bell, S. J., Auh, S., \& Smalley, K. (2005). Customer relationship dynamics: Service quality and customer loyalty in the context of varying levels of customer expertise and switching costs. Journal of the Academy of Marketing Science, 33, 169-183.

[10]. Berry, L.L. (2000), "Cultivating service brand equity", Journal of the Academy of Marketing Science, Vol. 28, pp. 128-37, Winter.

[11]. Bigne', J.E., Marte'nez, C., Miquel, M.J. \& Andreu, L., (2003). SERVQUAL reliability and validity in travel agencies. Annals of Tourism Research, 30(1), 258-62.

[12]. Bolton, R. N., \& Drew, J. H. (1991). A longitudinal analysis of the impact of service changes on customer attitudes. Journal of Marketing, 55(1), 1-9.

[13]. Chitty, B., Ward, S., Chua, C. (2007), "An application of the ESCI model as a predictor of satisfaction and loyalty for backpacker hostels", Marketing Intelligence \& Planning, Vol. 25 No.6, pp.563-80.

[14]. Cobb-Walgren, C.J., Ruble, C.A., \& Donthu, N., (1995). Brand equity, brand preference, and purchase intent. Journal of Advertising, 24, 25-40.

[15]. Cretu, A. E., \& Brodie, R. J. (2007). The influence of brand image and company reputation where manufacturers market to small firms: a customer value perspective. Industrial Marketing Management, 36(2), 230-240.

[16]. Cronin, J. and Taylor, S. (1992) "Measuring service quality: a re-examination and extension", Journal of Marketing, Vol. 56, No.3, pp. 55-68.

[17]. Dyson, P., Farr, A., \& Hollis, N.S.(1996). Understanding, measuring, and using brand equity. Journal of Advertising Research, 36(6), 9-21.

[18]. Ekinci, Y. (1999). An examination of generic service quality dimensions for the evaluation of hotels. Unpublished doctoral dissertation, University of Surrey, Guildford, England, United Kingdom.

[19]. Farquhar, P.H., (1989). Managing brand equity. Journal of Marketing Research, 1, 24-47.

[20]. Forgacs, G. (2003), "Brand asset equilibrium in hotel management", International Journal of Contemporary Hospitality Management, Vol. 15 No.6, pp. 340-342.

[21]. Getty, J. M., \& Thompson, K. N., (1994). The relationship between quality, satisfaction, and recommending behavior in lodging decision. Journal of Hospitality and Leisure Marketing, 2(3), 3-22.

[22]. Getty, J.M., \& Getty, R.L.(2003). Lodging quality index (LQI): Assessing customers' perceptions of quality deliver. International Journal of Contemporary Hospitality Management, 15(2), 94-104.

[23]. Gibson, A. (2003). The International Hospitality Industry Structure, Characteristics and 
Issues. In B. Brotherton (Ed.). Oxford: Butterworth-Heinemann.

[24]. Gronroos, C., (1988). Service quality: The six criteria of good perceived service quality. Review of Business, 9(3), 10-13.

[25]. Jones, M.A., Beatty, S.E., \& Mothersbaugh, D.V., (2002). Why customers stay: measuring the underlining dimensions of services switching costs and managing their differential strategic outcomes. Journal of Business Research, 55,441-50.

[26]. Juwaheer, T. D., (2004). Exploring international tourists' perceptions of hotel operations by using a modified SERVQUAL approach: A case study of Mauritius. Managing Service Quality 14, 350-364.

[27]. Kandampully, J., \& Hu, H. H. (2007). Do hoteliers need to manage image to retain loyal customers? International Journal of Contemporary Hospitality $435-443$

[28]. Kapferer, J.N. (2004), The New Strategic Brand Management, Kogan Page, London.

[29]. Kayaman, R., \& Arasli, H. (2007). Customer based brand equity: Evidence from the hotel industry. Managing Service Quality, 17(1), 92-109.

[30]. Keller, K. L. (2003). Strategic brand management: Building, measuring, and managing brand equity. Upper Saddle River, NJ: Prentice-Hall.

[31]. Keller, K.L. and Lehmann, D.R. (2006), "Brands and branding: research findings and future priorities", Marketing Science, Vol. 25 No. 6, pp. 740-59.

[32]. Keller, K.L.,(1993). Conceptualizing, measuring and managing customer-based brand equity. Journal of Marketing, 57, 1-22.

[33]. Khan, M.,(2003). ECOSERV: eco-tourists' quality expectations. Annals of Tourism Research, 30(1), 109-24.

[34]. Kim, H., \& Kim, W.G., (2005). The relationship between brand equity and firms' performance in luxury hotels and restaurants. Tourism Management, 26, 549-60.

[35]. Kim, H., Kim, W., \& An, J. (2003). The effect of customer-based brand equity on firms' financial performance. Journal of Customer Marketing. 20(4), 335-351

[36]. Kim, W.G., Jin-Sun, B. and Kim, H.J. (2008), "Multidimensional customer-based brand equity and its consequences in midpriced hotels", Journal of Hospitality and Tourism Research, Vol. 32 No. 2, pp. 235-54.

[37]. Knutson, B., Stevens, P., Wullaert, C., Patton, M., \& Yokoyama, F., (1990). LODGSERV: a service quality index for the lodging industry, Hospitality Research Journal, 14 (2), 227-84.

[38]. Landrum, H., Prybutok, V.R., Zhang, X. (2007), "A comparison of Magal's service quality instrument with SERVPERF", Information \& Management, Vol. 44 No.1, pp.104-13.

[39]. Mei, A. W. O., \& Dean, A. M., \& White, C. J. (1999). Analysing service quality in the hospitality industry. Managing Service Quality, 9(2), 136-143.

[40]. Michell, P., King, J., \& Reast, J. (2001). Brand values related to industrial products, Industrial Marketing Management, 30(5), 415425 .

[41]. Oberoi, U., \& Hales, C., (1990). Assessing the quality of conference hotel service product: towards an empirical based model. The Service Industries Journal, 10 (4), 700-721.

[42]. Olsen, M. D., West, J., \& Tse, E. (1998), Strategic Management in the Hospitality Industry (2 ed.), John Wiley \& Son, New York.

[43]. Parasuraman, A., Berry, L. L., \& Zeithaml, V. A. (1991). Refinement and reassessment of the SERVQUAL scale. Journal of Retailing, 67, 420-450.

[44]. Parasuraman, A., Zeithaml, V.A. \& Berry, L.L., (1988). SERVQUAL: a multiple item scale for measuring customer perception of service quality. Journal of Retailing, 64, 12-37.

[45]. Parasuraman, A., Zeithml, V. A., \& Berry, L., (1985). A conceptual model of service quality and its implications for future research. Journal of Marketing, 49(4), 41-50.

[46]. Prasad, K., \& Dev, C.S., (2000). Managing hotel brand equity. Cornell Hotel and Restaurant Administration Quarterly, 41(3), 22-31

[47]. Roses, L.K., Hoppen, N. \& Henriqu, J.L., (2009). Management of perceptions of information $\begin{array}{lllllll}\text { technology } & \text { service } & \text { quality. Journal of } & \text { Business } & \text { Research, } & \text { 62 }\end{array}$ Saleh, F., \& Ryan, C. (1991). Analyzing service quality in the hospitality industry using the SERVQUAL model. The Service Industries Journal, 11(3), 324-343.

[48]. Suhartanto, D. (2011), "An Examination of Brand Loyalty in the Indonesian Hotel Industry", Lincoln University Digital Thesis, Christchurch New Zealand

[49]. Wilkins, H., Merrilees, B., \& Herington, C. (2007). Towards an understanding of total service quality in hotels. Hospitality Management, 26(4), 840-853.

[50]. World Economic Forum, Travel and Tourism Competitiveness Report (2011.)

[51]. Zeithaml, V.A. (1988). Consumer perceptions of price, quality, and value: a means-end model and synthesis of evidence. Journal of Marketing, 52, 2-22, July. 